\title{
$\mathrm{Si}-\mathrm{M}-\mathrm{C}-\mathrm{O}$ 繊維結合型セラミックスの機械的特性に及ぼす マトリックス構造の影響
}

\author{
梶井紳二·石川敏弘・松永賢二·布上俊彦 $\cdot$ 幡中憲治* \\ 宇部興産(株)宇部研究所, 755-8633 宇部市大字小串 1978-5 \\ *山口大学工学部, 755-8611 宇部市常盤台 2557
}

\section{Influence of Matrix Structure on Mechanical Property of Si-M-C-O Fiber-Bonded Ceramics}

\author{
Shinji KAJII, Toshihiro ISHIKAWA, Kenji MATSUNAGA, Toshihiko HOGAMI and Kenji HATANAKA* \\ Ube Research Laboratory, Ube Industries, Ltd., 1978-5, Kogushi, Ube-shi 755-8633 \\ * Department of Engineering, Yamaguchi University, 2557, Tokiwadai, Ube-shi 755-8611
}

\begin{abstract}
The microstructure and mechanical properties of $\mathrm{Si}-\mathrm{Ti}-\mathrm{C}-\mathrm{O}$ and $\mathrm{Si}-\mathrm{Zr}-\mathrm{C}-\mathrm{O}$ fiber-bonded ceramics, produced by hot-pressing a laminated material of pre-oxidized $\mathrm{Si}-$ ( $\mathrm{Ti}$ or $\mathrm{Zr}$ )-C-O fibers, were investigated. The Si-Ti-C-O fiber-bonded ceramic had a close-packed structure of fibers with a volume fraction of $85 \%$ and $\mathrm{a} \mathrm{SiO}_{2}$-based oxide matrix including $\mathrm{TiC}$ particles. On the other hand, the $\mathrm{Si}-\mathrm{Zr}-\mathrm{C}-\mathrm{O}$ fiber-bonded ceramic consists of a close-packed structure with a volume fraction of $83 \%$ and a $\mathrm{SiO}_{2}$-based oxide matrix without any precipitated phase. Moreover, an interfacial carbon layer is constructed around all the fiber elements in both the fiber-bonded ceramics during the hot-pressing. The high-temperature flexural strength was much higher in the Si-Ti-C-O fiber-bonded ceramic than in the Si-Zr-C-O one. This was thought to be due to the $\mathrm{SiO}_{2}$-matrix in the $\mathrm{Si}$-Ti-C-O fiber-bonded ceramic, which seems to be refrained from the softening effect by dispersed $\mathrm{TiC}$ particles at high temperature.
\end{abstract}

[Received April 26, 2000; Accepted September 20, 2000]

Key-words : Ceramics composite, Silicon-titanium-carbon-oxygen fiber, Silicon-zirconium-carbon-oxygen fiber, Bending strength, Microstructure

\section{1. 緒言}

セラミックスは耐熱性，比強度，耐食性に優れているが，割 れやすいという久点を持っている。 そこで, 各種無機緘維を強 化材としたセラミックス基複合材料 (CMC) の開発研究が積 極的に行われている1) 5). CMC は強化繊維，マトリックスと もに脆性であるが，繊維ーマトリックスの界面強度を制御し， 以下に示す複雑な破壊過程を実現することにより高い勒性を実 現している，CMCにおける破壊過程はおもに，(1)マトリッ クスクラッキング，(2)界面はく離，(3)繊維破断・プルアウ ト，の三つに分類される. 比較的低応力でマトリックスに生じ たクラックは，マトリックス-繊維の界面に達し界面層におい て界面はく離を生じる. 応力の増加に伴い界面はく離が進行す るが，臨界長さに達したのちクラックは繊維中を進展し繊維破 断とプルアウトを生じさせる．更に，クラックはマトリックス に進展する。すなわち， $\mathrm{CMC}$ 材料では破壊に達するまでに上 記 3 種類の過程が材料内部で複雑に繰り返されている.とこ ろで，CMC 材料の製造プロセスとして PIP (precursor impregnation and pyrolysis) 法, CVI (chemical vapor infiltration) 法 などが挙げられる。これらの方法ではマトリックスは数十\%の 割合で含有される.

先述したように, $\mathrm{CMC}$ 材料では破壊の起点はマトリックス クラッキングにより生じると言われている。 マトリックスク ラッキングは比較的低応力で生じ，マトリックスー繊維界面の 界面はく離の進展により CMC 材料の応力-歪曲線は非線形な 応答を示す． CMC 材料ではマトリックスクラッキングが低応 力で生じるため弾性変形領域は小さく, 比較的小さな比例限界 值を示す.したがって，勒性に優れた CMC 材料においても実 際に使用可能な応力範囲は, 弾性変形領域すなわち比例限界以 下の応力範囲となる。これがいまだに CMC の実用化が進まな
い要因の一つと言われている.

$\mathrm{Si}-\mathrm{Ti}-\mathrm{C}-\mathrm{O}$ 繊維結合型セラミックスは次に示すように前述 した従来型の CMC とは異なる. Si-Ti-C-O 繊維を酸化処理 して, 表面に数百 $\mathrm{nm}$ の酸化層を生成させた酸化 $\mathrm{Si}-\mathrm{Ti}-\mathrm{C}-\mathrm{O}$ 繊維をホットプレスして得られる繊維結合型セラミックスは, 製造過程における高温高圧の条件下で繊維の表面酸化層が最密 に充填した緎維の隙間を埋めるマトリックス相を構成し, 繊維 の体積含有率が85 90 vol\%という非常に高いユニークな材料 である，そして，繊維同士及び繊維とマトリックス相との境界 には厚さ $10 \sim 20 \mathrm{~nm}$ の炭素層が生成している. Si-Ti-C-O 纎 維結合型セラミックスの破壊は，モノリシックセラミックスの ように脆性的ではなく最大荷重に達した後, 間欠的に荷重の低 下が生じる非線型的な形態を示し，1673 K 以上の大気中でも 優れた力学的特性を保持する6). 境界炭素層は製造過程におけ る高温高圧の条件下で, 繊維中に存在していた余㮃炭素が粒界 拡散により繊維表面に達して形成する．この境界炭素層が滑り 層として機能し，マトリックスの早期破断により発生したク ラックの繊維への進展を妨げることにより，前述のような破壊 形態が観察されたと考えられている7). Si-Ti-C-O 繊維結合型 セラミックスの境界炭素層の存在状態と曲げ強度及び層間せん 断強度々の関係 $\left.{ }^{8}\right)$ 及び, 纎維体積含有率がその高温力学的特性 に及ぼす影響9にについて既に報告している，ところで，原料纎 維の表面酸化層は, 主として $\mathrm{SiO}_{2}$ と $\mathrm{TiO}_{2}$ からなるが, 得ら れた Si-Ti-C-O 繊維結合型セラミックスのマトリックス相 は, $50 \mathrm{~nm}$ 以下の $\mathrm{TiC}$ の微結晶が非晶質 $\mathrm{SiO}_{2}$ 中に分散したナ ノ粒子分散構造に変化している.このマトリックス相中の $\mathrm{TiC}$ は，ホットプレスの過程に拈いて $\mathrm{SiO}_{2}$ と $\mathrm{TiO}_{2}$ の共晶温度 $1823 \mathrm{~K}$ 以上で䋊維中の余剰炭素と $\mathrm{TiO}_{2}$ の反応により生成し ている10). 
このようなユニークな特徵を有する Si-Ti-C-O 繊維結合型 セラミックスは, 高温構造用材料として期待されており, 上述 のとおり, 本材料の力学的特珄ならびに微細構造についてこれ までにも多くの知見を得てきているが，マトリックス中に分散 した50 nm 以下の $\mathrm{TiC}$ 微結晶がこの材料の力学的性質に及ぼ す効果については明らかにされていなかった．Si-Ti-C-O 緎 維を用いた緘維結合型セラミックスでは, ホットプレス過程に in-situでマトリックス中に TiC 微結晶が生成するため, $\mathrm{TiC}$ 微結晶の生成を抑制することは困難であった，そこで，本研究 では, Si-Ti-C-O 繊維 ${ }^{11)}$ に比べて高温まで $\mathrm{SiC}$ 結晶の成長が 抑えられ耐熱性に優れた $\mathrm{Si}-\mathrm{Zr}-\mathrm{C}-\mathrm{O}$ 繊維 ${ }^{12)}$ を出発原料として 合成した $\mathrm{Si}-\mathrm{Zr}-\mathrm{C}-\mathrm{O}$ 繊維結合型セラミックスを比較材に用い て, 構造及び力学的特性の違いについて調べ, $\mathrm{Si}-\mathrm{Ti}-\mathrm{C}-\mathrm{O}$ 緎 維結合型セラミックスのマトリックス中に分散した $\mathrm{TiC}$ 微結 晶がこの材料の力学的特性に及ぼす効果について検討する.

\section{2. 実 験}

\section{1 試 料}

出発原料としては, 非晶質構造を持つ $\mathrm{Si}-\mathrm{Ti}-\mathrm{C}-\mathrm{O}$ 繊維（チ

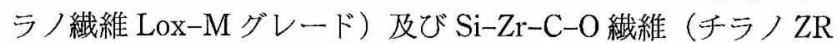
繊維）の 2 種類の $\mathrm{SiC}$ 系無機繊維を用いた。これらの繊維は それぞれポリチタノカルボシラン及びポリジルコノカルボシラ ンを溶融紡禾した後, 不融化, 焼成して合成される. 表 1 に $\mathrm{Si}-\mathrm{Ti}-\mathrm{C}-\mathrm{O}$ 繊維（チラノ緎維 Lox-M グレード）及び $\mathrm{Si}-\mathrm{Zr}-$ $\mathrm{C}-\mathrm{O}$ 繊維（チラノ ZR 繊維）の諸特性を示す．これらの繊維 を $1273 \mathrm{~K}$ の空気中で熱処理して, 表面に400 nm の酸化層を有 する酸化繊維を得た，それぞれの酸化繊維をシート状に成形し た後, 繊維方向をそろえて積層した一方向プリフォームを, Arガ久雾团気中, $2023 \mathrm{~K}, 1 \mathrm{~h}, 40 \mathrm{MPa}$ の条件でホットプレス 処理して, Si-Ti-C-O 繊維結合型セラミックス及び $\mathrm{Si}-\mathrm{Zr}-$ C-O 緎維結合型セラミックスをそれぞれ合成した. 合成力法 を図 1 に示す。得られたこれら 2 種類の成形体をそれぞれ

Table 1. Chemical Compositions of $\mathrm{Si}-\mathrm{Ti}-\mathrm{C}-\mathrm{O}$ and $\mathrm{Si}-\mathrm{Zr}-\mathrm{C}-\mathrm{O}$ Fibers

\begin{tabular}{ccc}
\hline Sample & Composition $/$ mass $\%$ & Chemical formula \\
\hline \multirow{2}{*}{ Si-Ti-C-O fiber } & Si:52.5, Ti:3.0, & $\mathrm{Si}_{1} \mathrm{Ti}_{0.03} \mathrm{C}_{1.4} \mathrm{O}_{0.4}$ \\
& $\mathrm{C}: 34.4, \mathrm{O}: 10.7$ & \\
\multirow{3}{*}{ Si-Zr-C-O fiber } & $\mathrm{Si}: 54.5, \mathrm{Zr}: 1.0$, & $\mathrm{Si}_{1} \mathrm{Zr}_{0.01} \mathrm{C}_{1.4} \mathrm{O}_{0.4}$ \\
& $\mathrm{C}: 33.3, \mathrm{O}: 10.1$ & \\
\hline
\end{tabular}

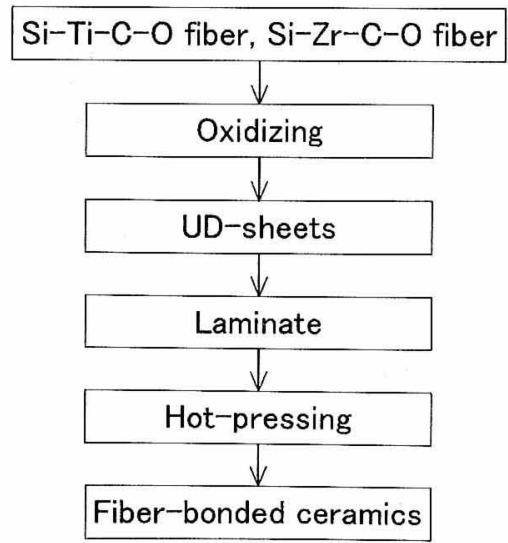

Fig. 1. Production process of the fiber-bonded ceramic.
$\mathrm{FBC}(\mathrm{Lox}-\mathrm{M})$ 及び $\mathrm{FBC}(\mathrm{ZR})$ と呼ぶこととする.

\section{2 試験方法}

纎維軸方向の曲げ強度は, 島津製作所製オートグラフ （DSS-500）を用いて, 空気中室温, $1673 \mathrm{~K}$ 及び $1773 \mathrm{~K}$ の温 度で, 上部スパン長さ $10 \mathrm{~mm}$, 下部スパン長さ $30 \mathrm{~mm}$, クロ スヘッド速度 $0.5 \mathrm{~mm} / \mathrm{s}$ で四点曲げ試験を実施することにより 得た. 試験片の寸法は, 幅 $4 \mathrm{~mm} \times$ 高さ $3 \mathrm{~mm} \times$ 長さ $40 \mathrm{~mm}$ と した、試験本数は，すぺての試験において 1 条件につき 3 本 とした.

繊維結合型セラミックスの断面組織観察は, 繊維にほぼ垂直 に切断した試験片の断面を鏡面研磨したのち Arイオンエッチ ングを施し日立製作所製走査型電子顕微鏡（FE-SEM; S5000）を用い，加速電圧 $10 \mathrm{kV}$ で行った．緎維ーマトリックス 相界面近傍の微細構造観察は日本電子製, 高分解能透過型電子 顕微鏡（JEM-2010）を用いて加速電圧 $200 \mathrm{kV}$ で行い, 元素 分析は透過電子顕微鏡付属のエネルギー分散型 $\mathrm{X}$ 線分析装置 (TEM-EDX) を用いて行った.

\section{1 組織観察}

\section{3. 実験結果及び考察}

図 2 に FBC (Lox-M) の断面の FE-SEM 写真を示す. 直佳 $8 \mu \mathrm{m}$ 程度の円形の断面形状を保持した緎維はほぼ最密に充填 され，原料繊維の表面酸化層が繊維を結合するマトリックス相 を形成している、広範囲の断面組織観察結果から，気孔の極め て少ない緻密な構造をしていることを確認しており，緎維部分 とマトリックス相部分の面積比から算出した繊維体積率 $\left(V_{\mathrm{f}}\right)$ は85 vol\%であった. 繊維の回りに暗いコントラストを呈して いる層が $\mathrm{Ar}$ イオンエッチングで選択研磨された炭素層で，こ れはホットプレスの過程で繊維中の余剩炭素が遊離析出して生
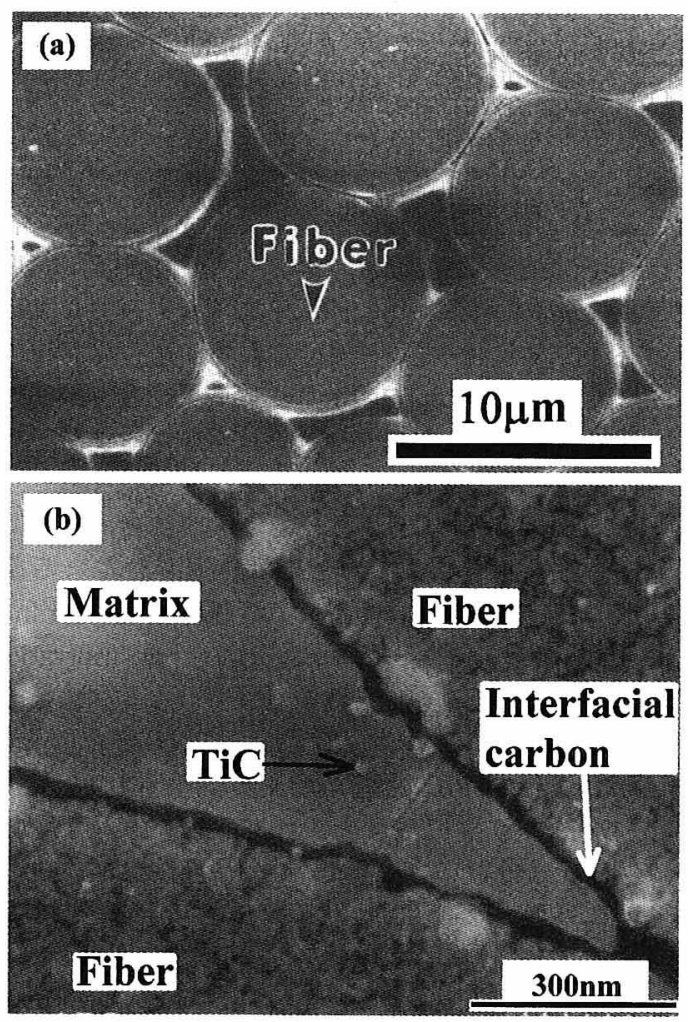

Fig. 2. SEM photographs in cross section of $\mathrm{Si}-\mathrm{Ti}-\mathrm{C}-\mathrm{O}$ fiberbonded ceramic.

(a) General observation, (b) enlarged observation. 

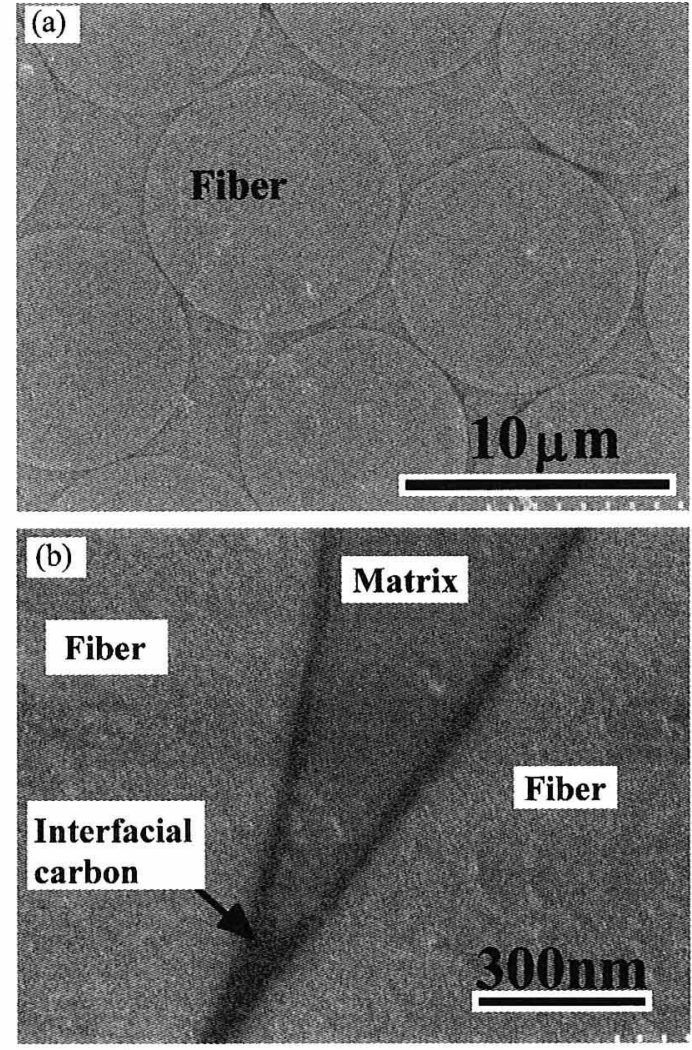

Fig. 3. SEM photographs in cross section of $\mathrm{Si}-\mathrm{Zr}-\mathrm{C}-\mathrm{O}$ fiberbonded ceramic.

(a) General observation, (b) enlarged observation.

成したものである. 更に, FBC (Lox-M) の瀻維間に存在する マトリックス相は非晶質シリカ中に数十 $\mathrm{nm}$ の $\mathrm{TiC}$ 微粒子か゚ 分散した複合構造をとっている.

図 3 は FBC (ZR) の断面組織である。この場合もほぼ円形 の断面形状を保持した直径 $8 \mu \mathrm{m}$ 程度の㵶維が最密充媜構造を 取り, 繊維の回りには10 20 nm の境界炭素層が生成してい る. また，繊維と繊維の隙間は非晶質酸化物からなるマトリッ クス相で充填されている. 広範囲の断面組織観察結果から,こ の材料においても気孔の極めて少ない緻密な構造が確認されて おり, 繊維部分とマトリックス相部分の面積比から算出した繊 維体積率 $\left(V_{\mathrm{f}}\right)$ は83 vol\%であった. 更に, 緎維の回りには幅 $20 \mathrm{~nm}$ 程度の層が存在する。この層は $\mathrm{FBC}(\mathrm{Lox}-\mathrm{M})$ におけ ると同様にホットプレスの過程に繊維中の余剩炭素が遊離析出 して生成した炭素層である.しかし, FBC (Lox-M) のマト リックス相で認められた TiC 微結晶粒子に代わる $\mathrm{ZrC}$ の分散 は, $\mathrm{FBC}(\mathrm{ZR})$ のマトリックス相中には認められなかった. ホットプレスの過程で, 酸化チラノ ZR 繊維の表面酸化層中の $\mathrm{SiO}_{2}$ と $\mathrm{Zr}$ 酸化物がホットプレスの過程中, 安定な共融点化合 物（ジルコン）を形成すると考えられる. この共融点化合物中 に存在する Zr は酸素と強固に結合しており, 繊維の構造変化 に起因して繊維内部加ら拡散して出てくる余剩炭素と反応し難 いことから， Zro炭化物を形成しないと考元られる.

図 4 に FBC (Lox-M) の繊維ーマトリックス相界面近傍の TEMにより観察した組織及び繊維一マトリックス界面層に対 応する制限視野回折像を示す. 非晶質構造を取っていた緎維相 はホットプレス過程中, 構造変化を生じ非晶質中に数〜数百 $\mathrm{nm}$ の粒径分布をもつ $\mathrm{SiC}$ 結晶, $\mathrm{TiC}$ 結晶及びカーボンリボン
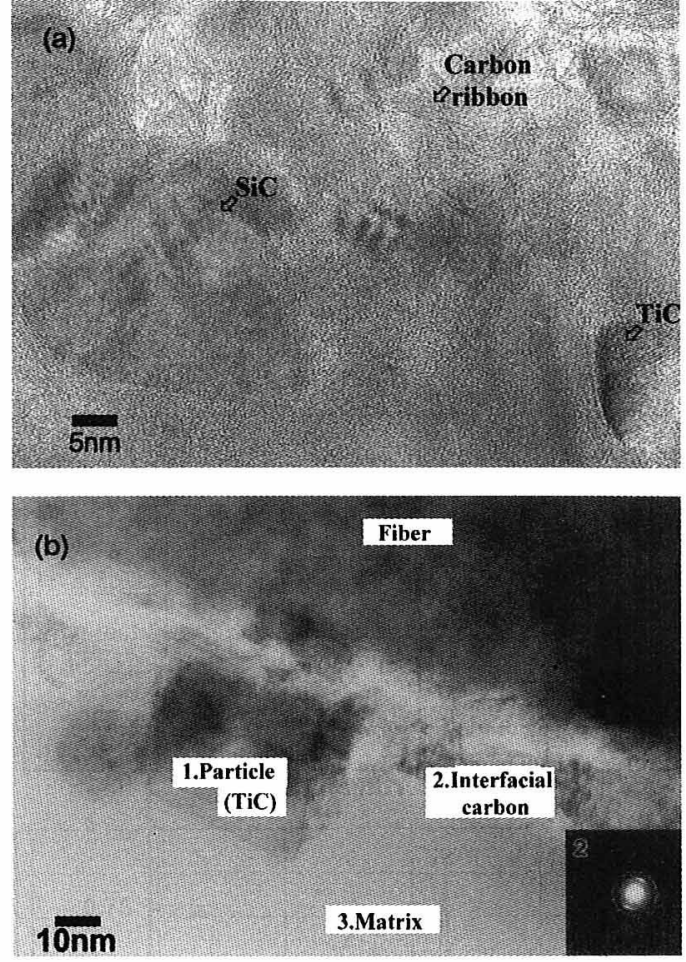

Fig. 4. TEM image and selected area diffraction pattern of $\mathrm{Si}-\mathrm{Ti}-\mathrm{C}-\mathrm{O}$ fiber-bonded ceramic.

(a) Fiber element, (b) fiber-matrix interface.

が分散していることが分かる，緎維表面に生成している炭素層 の厚さは約 $20 \mathrm{~nm}$ で，炭素の積層面である(002)面がほぼ繊維 外周に沿って配向していることが格子像及び制限視野回折像で 確認された，更に，境界炭素層一マトリックス相界面に生成し た結晶粒子 (1) は TiCであることが TEM-EDX 元素分析結果 より明らかとなった。 またこの $\mathrm{TiC}$ 結晶粒子とマトリック 又相の界面にも境界炭素層が生成していることが分かった。こ れより，遊離析出した余㮃炭素は酸化物中に拡散し $\mathrm{TiO}_{2}$ と反 応し $\mathrm{TiC}$ を形成した後, $\mathrm{TiC}$ 結晶粒子とマトリックス相の界 面にも境界炭素層を形成したと考えられる.図 5 に示した TEM-EDX による元素分析結果より, 粒子 (1)は TiC 結晶, 界面層(2)はカーボン, マトリックス(3)は $\mathrm{SiO}_{2}$ であることが 確認された。

図 6 に $\mathrm{FBC}(\mathrm{ZR})$ の繊維ーマトリックス相界面近傍の TEM により観察した組織及び境界層の制限視野回折像を示す。 た，TEM-EDXによる元素分析結果を図 7 に示す. 非晶質構 造を取っていた緎維相はホットプレスの過程で構造変化を生 じ，非晶質中にこれに起因して生成した数〜数十 $\mathrm{nm}$ の粒径分 布をもつ $\mathrm{SiC}$ 結晶及びカーボンリボンが分散している. 繊維 表面に生成している炭素層の厚さは約 $20 \mathrm{~nm}$ で, 炭素の積層 面である(002)面が緘維外周に沿ってほぼ配向していることが 格子像及び制限視野回折像で確認された。ママリックス相は均 一な非晶質シリカ相であることが電子線回折及び TEM-EDX による元素分析結果から確認できる.図 7 に示したTEMEDXによる元素分析結果より界面層 (2)はカーポン, マト リックス(3) $\mathrm{SiO}_{2}$ であることが確認された。 マトリックス 相の元素分析によっては Zr は認められていないが，これは原 料繊維中の $\mathrm{Zr}$ は 1 mass\% $\%$ 低濃度で, $\mathrm{SiO}_{2}$ 中に均一に固溶 しているために検出されなかったものと考えている. 


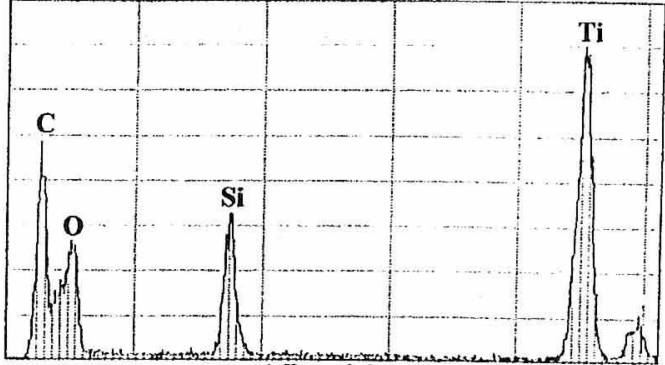

1.Particle

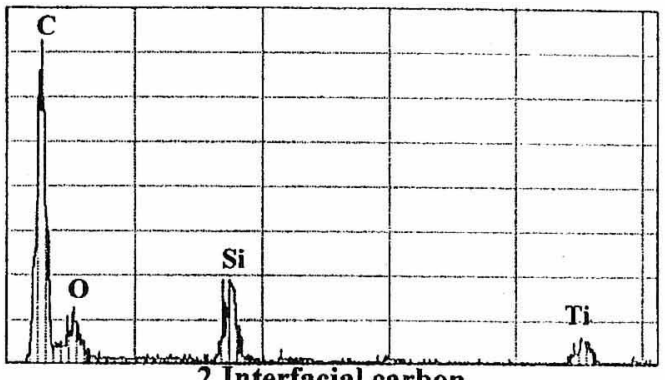

nterfacial carbon

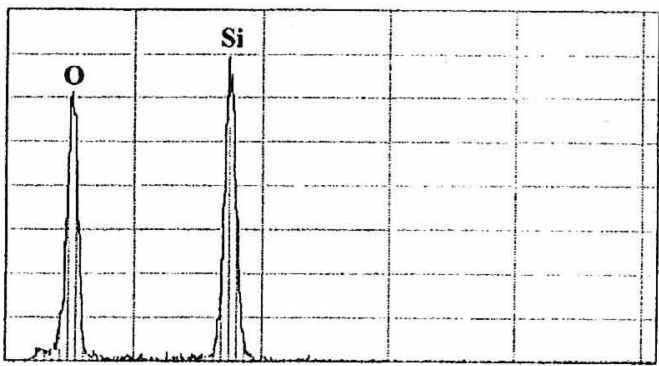

3.Matrix

Fig. 5. TEM-EDX spectra at the points 1, 2 and 3 in Fig. 4.

本供試体に打いて $\mathrm{FBC}(\mathrm{ZR})$ の繊維相に含まれる $\mathrm{SiC}$ 結晶の 成長が， $\mathrm{FBC}(\operatorname{Lox}-\mathrm{M})$ の繊維相のそれに比較して抑制されて いた．この理由を論じるためには，㵶維相中の余剰炭素と $\mathrm{Si}$, $\mathrm{Ti}$ 及び $\mathrm{Zr}$ の酸化物の還元反応による炭化物の生成メカニズム を調べなければならない，これらの反応の典型的な例は以下の 式で示される.

$$
\begin{aligned}
& \mathrm{SiO}_{2}+3 \mathrm{C} \longrightarrow \mathrm{SiC}+2 \mathrm{CO} \\
& \mathrm{TiO}_{2}+3 \mathrm{C} \longrightarrow \mathrm{TiC}+2 \mathrm{CO} \\
& \mathrm{ZrO}_{2}+3 \mathrm{C} \longrightarrow \mathrm{ZrC}+2 \mathrm{CO}
\end{aligned}
$$

これらの反応が進行する温度域は，各反応における物質の生 成熱, 及びエントロピーの值 ${ }^{13)}$ から算出した標準自由エネル ギ一変化 $(\Delta G)$ の温度依存性の計算結果より(1)，(2)及び (3) 式でそれぞれ 1811, $1567 \mathrm{~K}$ 及び $1906 \mathrm{~K}$ 以上である。 FBC (Lox-M) のホットプレス過程における繊維相の構造変化につ いては，上記(1)式及び(2)式で示した反応を比較すると， $\mathrm{SiC}$ 結晶の生成より低温において $\mathrm{TiC}$ 結晶が生成すると考えられ る.これに対して, $\mathrm{FBC}(\mathrm{ZR})$ のホットプレス過程における繊 維相の構造変化については, 上記(1)式及び (2)式で示した反 応を比較すると， $\mathrm{ZrC}$ 結晶よりも低温で $\mathrm{SiC}$ 結晶の生成反応 が進行する. 一方, 先述したように $\mathrm{Zr}$ の酸化物は $\mathrm{SiO}_{2}$ と安定 な共融点化合物 (ジルコン)を形成すると考えられることより， FBC (ZR) では SiC 結晶の成長が抑制されたと推定している.

\section{2 曲げ強度の温度依存性}

図 8 に $\mathrm{FBC}(\mathrm{Lox}-\mathrm{M})$ 及び $\mathrm{FBC}(\mathrm{ZR})$ の 4 点曲げ強度の温
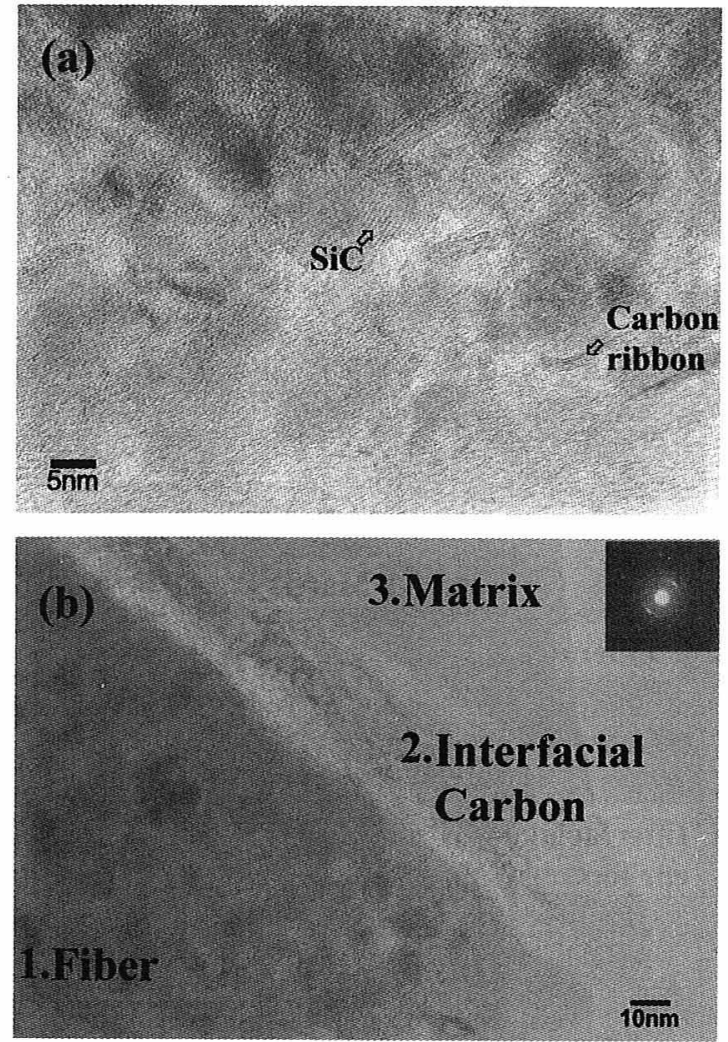

Fig. 6. TEM image and selected area diffraction pattern of $\mathrm{Si}-\mathrm{Zr}-\mathrm{C}-\mathrm{O}$ fiber-bonded ceramic.

(a) Fiber element, (b) fiber-martrix interface.

度依存性を示す，FBC(Lox-M) は $1673 \mathrm{~K}$ まで室温強度を保 持しており，1773 K で強度の低下が認められた。一方，FBC (ZR) の曲げ強度は, 試験温度の上昇とともに大きく低下し, $1673 \mathrm{~K}$ では室温強度の $50 \%$ 以下に減少する。これより，FBC (Lox-M) の方が FBC(ZR) に比べて高温むで優れた強度を保 持していることが分かる.

図 9 に室温から $1773 \mathrm{~K}$ をでの空気中で測定した FBC (LoxM) の 4 点曲げ試験における典型的な荷重一変位曲線を示す. これによると, $1673 \mathrm{~K}$ の高温なで塑性変形的な挙動は見られ ず， $1673 \mathrm{~K}$ で室温の場合と同様に最大荷重に達した後も間欠

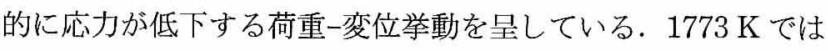
比較的低応力域でコンプライアンスが増加し, 最高荷重付近で 大きく降伏を示した後にせん断破壊に起因する大きな荷重の低

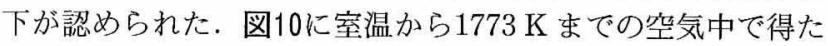
$\operatorname{FBC}(Z R) の 4$ 点曲げ試験における典型的な荷重一変位曲線を 示す，室温では，最大荷重に達した後も間欠的に応力が低下す る荷重-変位挙動を呈している。一方, $1673 \mathrm{~K}$ では比較的低い 応力值を越えた応力域でコンプライアンスが増加し, 非弾性的 挙動を示す. そして最高荷重に到達した直後, 急激な荷重低下 を示すが，その後も荷重を負担し続ける荷重一変位挙動を示し た. また, $1773 \mathrm{~K}$ では最高荷重に到達した後も急激な荷重低 下を示さず，荷重を負担し続ける挙動を示している.

$\mathrm{FBC}(\mathrm{Lox}-\mathrm{M})$ では室温〜 $1773 \mathrm{~K}$ の全温度域で, FBC (ZR) では室温において, 試験片下部面で引張りにより破壊した痕跡 が認められた．一方， $1673 \mathrm{~K}$ 及び $1773 \mathrm{~K}$ で破壊試験を行った $\mathrm{FBC}(\mathrm{ZR})$ では, 試験片には巨視的な破壊は認められず, 圧縮 応力側の上部ピンとの接触部で側面方向に膨らみが生じ, 永久 


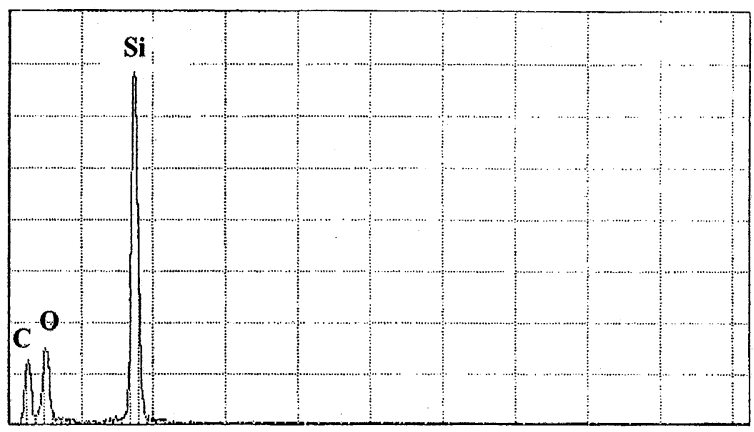

1.Fiber

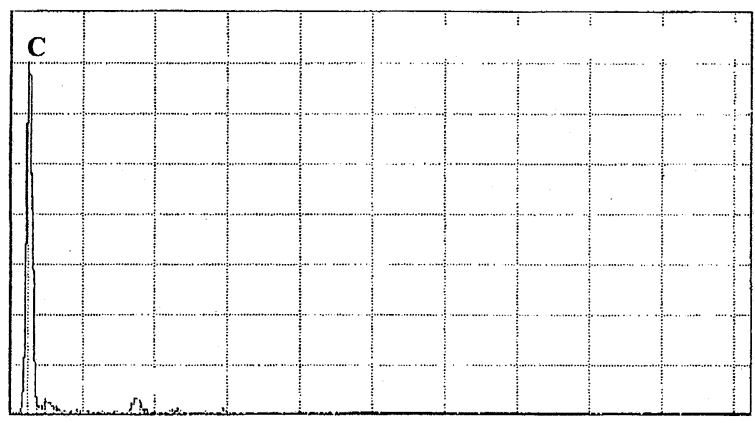

2.Interfacial Carbon

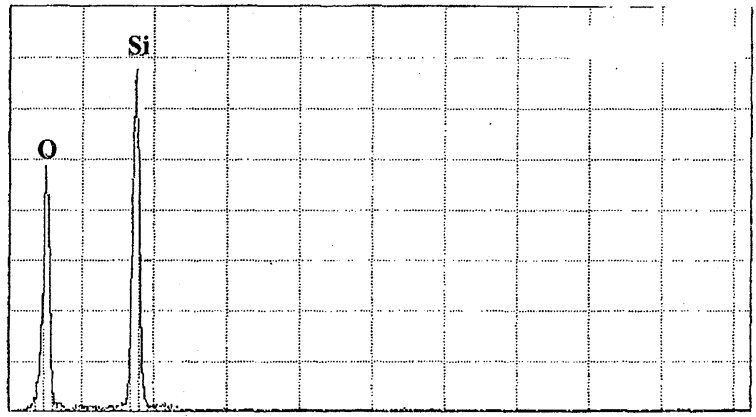

\section{Matrix}

Fig. 7. TEM-EDX spectra at the points 1,2 and 3 in Fig. 6.

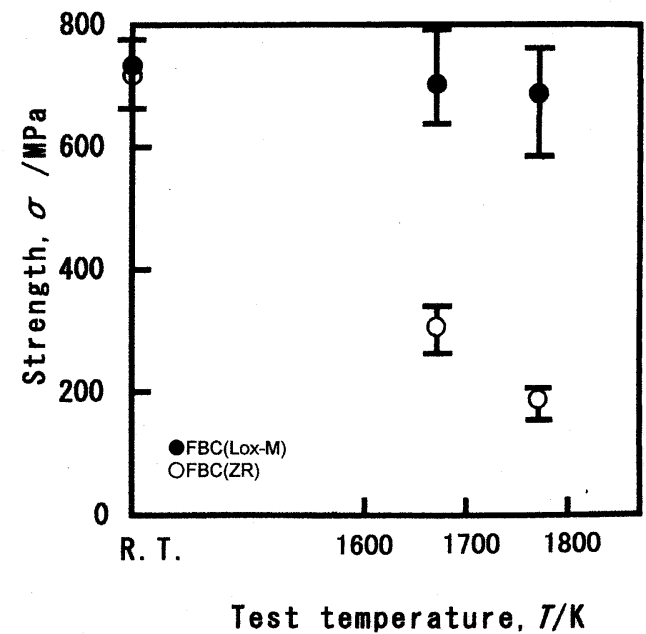

Fig. 8. Relationships between test temperature and four-point bending strength in $\mathrm{Si}-\mathrm{Ti}-\mathrm{C}-\mathrm{O}$ fiber-bonded ceramic and $\mathrm{Si}-\mathrm{Zr}-\mathrm{C}-\mathrm{O}$ fiber-bonded ceramic.

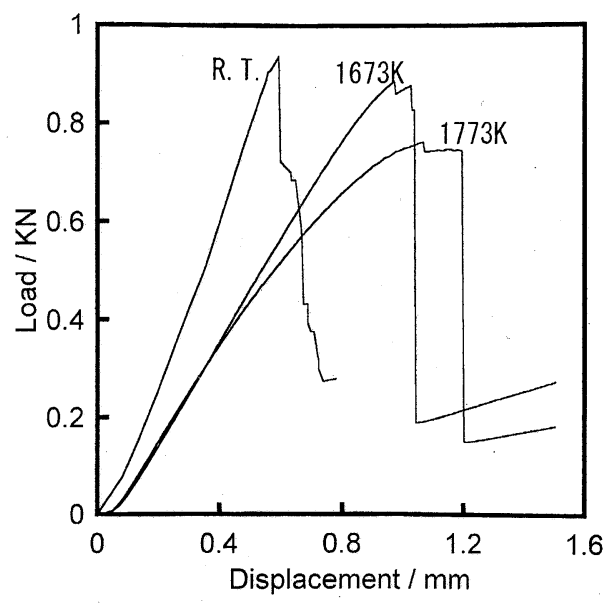

Fig. 9. Typical load-displacement curves in four-point bending test in $\mathrm{Si}-\mathrm{Ti}-\mathrm{C}-\mathrm{O}$ fiber-bonded ceramic at various temperatures.

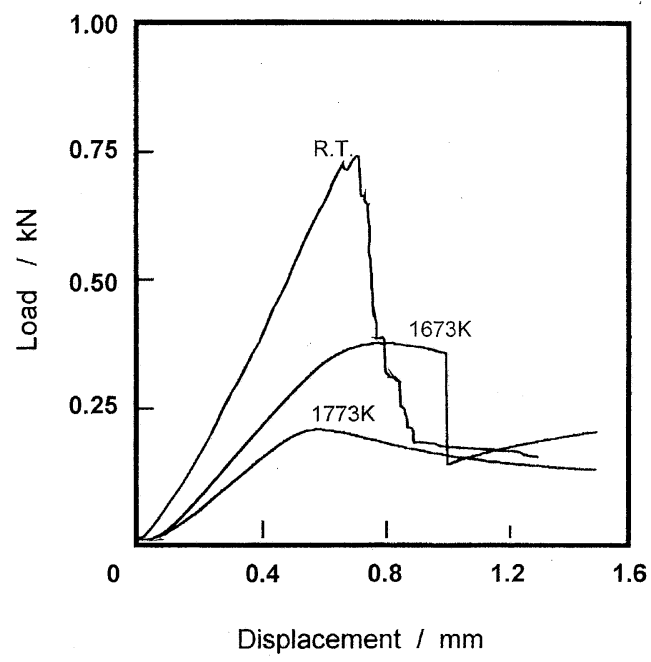

Fig. 10. Typical load-displacement curves in four-point bending test in $\mathrm{Si}-\mathrm{Zr}-\mathrm{C}-\mathrm{O}$ fiber-bonded ceramic at various temperatures.

曲げ変形が生じていた．図11に $1673 \mathrm{~K}$ の FBC (Lox-M) 曲げ 試験片で認められた代表的な引張り支配の破壊形態を, 図12に は, $1673 \mathrm{~K}$ の $\mathrm{FBC}(\mathrm{ZR})$ 曲げ試験片で認められた代表的な圧 縮支配の損傷形態を示す.

山岡らは, 本供試材の出発原料である $\mathrm{Si}-\mathrm{Ti}-\mathrm{C}-\mathrm{O}$ 繊維及び $\mathrm{Si}-\mathrm{Zr}-\mathrm{C}-\mathrm{O}$ 繊維を $\mathrm{Ar}$ ガス中で熱処理した繊維の強度と $\mathrm{SiC}$ 結 晶粒径の関係について調べている14)。このなかで $\mathrm{Si}-\mathrm{Zr}-\mathrm{C}-\mathrm{O}$ 繊維では, $\mathrm{Si}-\mathrm{Ti}-\mathrm{C}-\mathrm{O}$ 繊維におけるより $\mathrm{SiC}$ 結晶の成長が抑 制され，耐熱性が向上すると報告している，先述したように， この過程で本供試材 $\mathrm{FBC}(\mathrm{ZR})$ の繊維相に含まれる $\mathrm{SiC}$ 結晶の 成長は FBC $($ Lox $-\mathrm{M})$ に比較して抑制されており， FBC $(\mathrm{ZR})$ を構成する繊維相の強度は FBC (Lox-M) を構成する繊維相 の強度より優れていると考えられる.

また，著者らは先の研究で, $\mathrm{Si}-\mathrm{Ti}-\mathrm{C}-\mathrm{O}$ 繊維結合型セラ ミックスの繊維体積率がその高温力学的特性に及ぼす影響を明 らかにしている ${ }^{9)}$. 繊維体積率 $73 \mathrm{vol} \%$ の繊維結合型セラミッ クスの $1773 \mathrm{~K}$ での曲げ試験において圧縮支配の損傷形態を認 めた。一方，本供試材料である $\mathrm{FBC}(\mathrm{ZR})$ は繊維含有率が 83 vol\%である。このように繊維含有率が高いにもかかわらず 


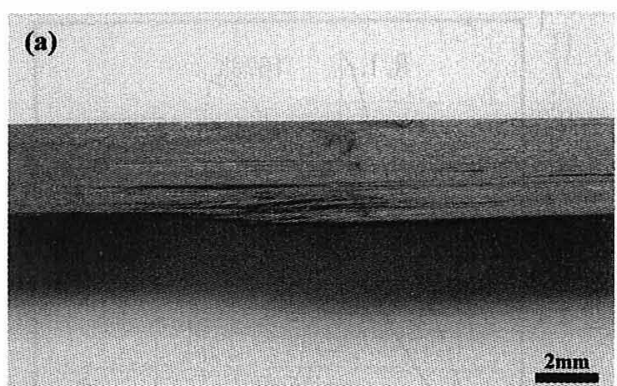

(b)

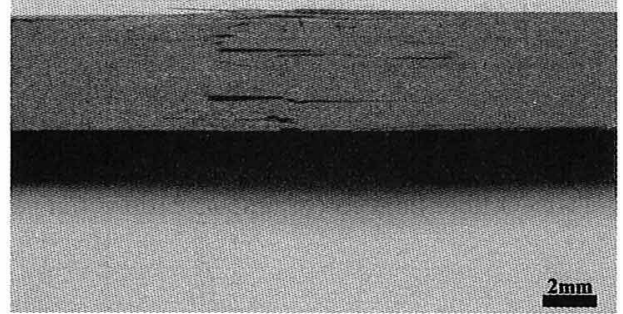

Fig. 11. Fracture patterns of $\mathrm{Si}-\mathrm{Ti}-\mathrm{C}-\mathrm{O}$ fiber-bonded ceramic by four-pont bending test at $1673 \mathrm{~K}$. (a) Side view, (b) bottom view (tensile side).

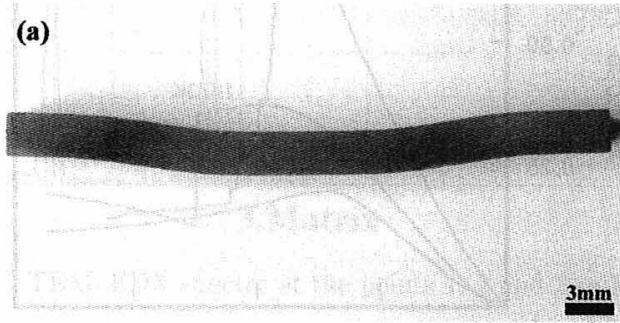

(b)

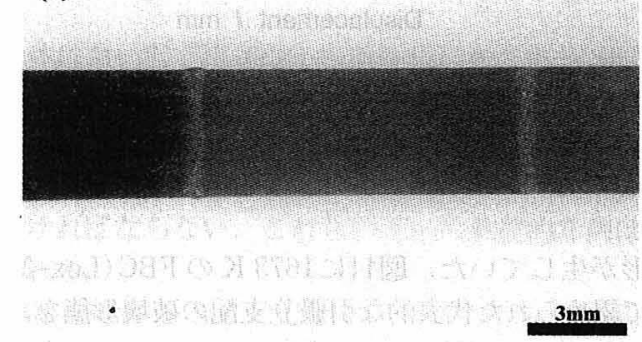

Fig. 12. Deformation patterns of $\mathrm{Si}-\mathrm{Zr}-\mathrm{C}-\mathrm{O}$ fiber-bonded ceramic by four-point bending test at $1673 \mathrm{~K}$. (a) Side view, (b) top view (compressive side).

FBC $(Z R)$ において圧縮支配の損傷が観察され，非常に大きく 強度が低下し，FBC(Lox-M) においてこれらが認められな かったのは，両材のマトリックス相の構造の相違に由来すると 考えられる. 繊維間のマトリックス相は両材とも前述したよう に非晶質の $\mathrm{SiO}_{2}$ を主体としている。非晶質の $\mathrm{SiO}_{2}$ は $1473 \mathrm{~K}$ 近辺にガラス転移点を有しており，同温度以上では粘性変形す る.したがって, 高温における圧縮強度の低下は酸化物マ卜 リックス相の粘性変形が大きく影響したと言える. そこで, $\mathrm{FBC}($ Lox $-\mathrm{M})$ 及び FBC (ZR) の繊維間に充填された酸化物マ トリックス相の構造に基づいて上記現象を考察する.

一般に粘性流動はごく少量の粒子の分散により著しく影響を
受けることが知られている，Brinkman は固体粒子の分散率と 粘性流体の粘度について次の式を提唱している15).

$$
\eta_{\mathrm{r}}=\left(1-\phi_{\mathrm{v}}\right)^{-2.5}
$$

ここで， $\phi_{\mathrm{v}}$ は固体粒子の体積率， $\eta_{\mathrm{r}}$ は相対粘度である. (4)式 より固体粒子の体積率の $5 \%$ の増加に対して相対粘度が $14 \%$ 程 度増加することが理解できる． FBC(Lox-M) のマトリックス 相は前述したように非晶質 $\mathrm{SiO}_{2}$ を主体とする酸化物に数十 $\mathrm{nm}$ の $\mathrm{TiC}$ 微結晶が分散した構造を有している。 TiC 粒子は 1773 Kにおいても粘性を示さないことから, FBC (Lox-M) に含まれるマトリックス相の高温に扔ける粘度は，微結晶粒子 の分散が認められない $\mathrm{FBC}(\mathrm{ZR})$ のマトリックス相に比べて 向上していると言える.

以上の考察より, $\mathrm{FBC}(\mathrm{Lox}-\mathrm{M})$ を構成する $\mathrm{TiC}$ 微結晶の 分散構造をとる非晶質 $\mathrm{SiO}_{2}$ を主体とするマトリックス相は, $\mathrm{FBC}(\mathrm{ZR})$ を構成する均一な構造をとる非晶質 $\mathrm{SiO}_{2}$ を主体と するマトリックス相に比較して高温におけるマトリックス相の 粘性流動が抑制されたことにより，FBC(Lox-M) は FBC (ZR) に比較して高温強度が向上したことが理解される。

\section{4. 総 括}

$\mathrm{Si}-\mathrm{Ti}-\mathrm{C}-\mathrm{O}$ 繊維を原料とする標準的な $\mathrm{Si}-\mathrm{Ti}-\mathrm{C}-\mathrm{O}$ 緘維結合 型セラミックスと $\mathrm{Si}-\mathrm{Zr}-\mathrm{C}-\mathrm{O}$ 繊維を原料として製造された $\mathrm{Si}-\mathrm{Zr}-\mathrm{C}-\mathrm{O}$ 緸維結合型セラミックスの室温から1773 K までの 空気中で 4 点曲げ破壊特性の違いについて調べ, Si-Ti-C-O 繊維結合型セラミックスの力学的特性に及ぼすマトリックス中 に分散した TiC 微結晶の効果について検討した。得られた結 果を以下にをとめる.

（1） Si-Ti-C-O 繊維結合型セラミックスの，非晶質 $\mathrm{SiO}_{2}$ を主体とするマトリックス相には数十 $\mathrm{nm}$ の $\mathrm{TiC}$ 微結晶が分 散していた。これに対して, Si-Zr-C-O 繊維より得られた繊 維結合型セラミックスのマトリックス相には微結晶粒子の生成 は認められず, マトリックス相は均一な非晶質 $\mathrm{SiO}_{2}$ の構造を とっていた.

（2） $\mathrm{Si}-\mathrm{Zr}-\mathrm{C}-\mathrm{O}$ 繊維結合型セラミックスにおいても $\mathrm{Si}-\mathrm{Ti}-$ $\mathrm{C}-\mathrm{O}$ 繊維結合型セラミックスと同様に緎維ーマトリックス相界 面には10２0 nm の境界炭素層の生成が認められた。

(3) 非晶質 $\mathrm{SiO}_{2}$ 中に $\mathrm{TiC}$ 結晶がナノ粒子分散したマト リックス相により構成された $\mathrm{Si}-\mathrm{Ti}-\mathrm{C}-\mathrm{O}$ 繊維結合型セラミッ クスでは, $1673 \mathrm{~K}$ まで室温強度を保持したのに比較して, 均 一な非晶質 $\mathrm{SiO}_{2}$ をマトリックス相とする $\mathrm{Si}-\mathrm{Zr}-\mathrm{C}-\mathrm{O}$ 繊維結合 型セラミックスは $1673 \mathrm{~K}$ 以上の温度に抢いて顕著な力学的特 性の低下が認められた。

（4） $\mathrm{Si}-\mathrm{Ti}-\mathrm{C}-\mathrm{O}$ 繊維結合型セラミックスの高温強度が $\mathrm{Si}-$ $\mathrm{Zr}-\mathrm{C}-\mathrm{O}$ 繊維結合型セラミックスに比較して高い原因の一つと して, マトリックス相に分散した $\mathrm{TiC}$ 結晶のナノ粒子分散効 果によるマトリックス相の粘性流動の抑制が考えられた。

\section{文献}

1) T. Ishikawa, K. Bansaku, N. Watanabe, Y. Nomura, M. Shibuya and T. Hirokawa, Comp. Sci. Technol., 58, 51-63 (1998).

2) Y. Kagawa and T. Kishi, J. Japan Inst. Metals, 56, 1470 (1992) [in Japanese].

3) K. Igashira, K. Nishio, H. Hino and S. Okazaki, J. Japan Inst. Metals, 62, 766-73 (1998) [in Japanese].

4) C. F. Windisch, Jr., C. H. Henager, Jr., G. D. Spronger and R. H. Johes, J. Am. Ceram. Soc., 80, 567-79 (1997).

5) H. Wang and R. N. Singh, J. Mater. Sci., 32, 3305-13 (1997).

6) T. Ishikawa, S. Kajii, K. Matsunaga, T. Hogami and Y. Kohtoku, J. Mater. Sci., 30, 6218-22 (1995). 
7) T. Ishikawa, S. Kajii, K. Matsunaga, T. Hogami and Y Kohtoku, Proc. of the 8th Int. Symposium on Ultra-High Temperature Materials (1994) pp. 55-61 [in Japanese].

8) K. Matsunaga, T. Ishikawa, S. Kajii, T. Hogami and Y. Kohtoku, J. Ceram. Soc. Japan, 103, 288-92 (1995) [in Japanese].

9) K. Matsunaga, T. Ishikawa, S. Kajii, T. Hogami and Y. Kohtoku, J. Japan Inst. Metals, 60, 1236-42 (1996) [in Japanese].

10) T. Ishikawa, S. Kajii, K. Matsunaga, T. Hogami and Y. Kohtoku, J. Soc. Mater. Sci. Japan, 45, 593-98 (1996) [in
Japanese].

11) T. Yamamura, T. Ishikawa, M. Shibuya, T. Hisayuki and K. Okamura, J. Mater. Sci., 23, 2589-94 (1988).

12) T. Ishikawa, Y. Kohtoku and K. Kumagawa, J. Mater. Sci., 33, 161-66 (1998)

13) D. D. Wagman, "The NBS Tables of Chem. Thermodyn. Prop.," NBS (1982).

14) H. Yamaoka, T. Ishikawa and K. Kumagawa, J. Mater. Sci., 34, 1333-39 (1999).

15) H. C. Brinkman, J. Chem. Phys., 20, 571 (1952). 